\title{
Analysis of Influence Factors on Stock Rate Through Distress Financial Level in Manufacture Company in 2010-2014
}

\author{
Mayang Murni ${ }^{* *}$, Supriyanto ${ }^{2}$, Masniati Murni Ritonga², Wardayani ${ }^{3}$, Zul Azmi $^{4}$, Hamdani $^{5}$, \\ Ismail $^{6}$, Dahlia ${ }^{7}$, Sisca Mediyanti ${ }^{8}$, Saiful Bahgia ${ }^{8}$ \\ \{mayang.ashari@gmail.com*\} \\ ${ }^{1}$ Department of Accounting, Politeknik LP3I Medan, Indonesia \\ ${ }^{2}$ Department of Business Administration, Politeknik LP3I Medan, Indonesia \\ ${ }^{3}$ Department of Management, Sekolah Tinggi Ilmu Manajemen Sukma Medan, Indonesia \\ ${ }^{4}$ Department of Accounting, University of Muhammadiyah Riau, Pekanbaru Indonesia \\ ${ }^{5}$ Department of Public Financial Management, Politeknik Kutaraja, Banda Aceh, Indonesia \\ ${ }^{6}$ Department of Office Administration, Politeknik Kutaraja, Banda Aceh, Indonesia \\ ${ }^{7}$ Department of Financial Analysis, Politeknik Kutaraja, Banda Aceh, Indonesia \\ ${ }^{8}$ Department of Accounting, Politeknik Kutaraja Banda Aceh, Indonesia
}

\begin{abstract}
The objective of this study was to examine the influence of size, firm age, CR, DER, ROA, ROE, NPM, EPS, and PER on stock price through financial distress level. The population was manufacture companies listed in BEI (the Indonesia Stock Exchange) in the period of 2010-2014. The samples were 73 manufacture companies listed in BEI, taken by using purposive sampling technique so that there were 365 observations. The data were secondary data which were obtained from financial statement. The result of the research showed that size, firm age, Current Ratio, and PER had positive and significant influence on stock rate. NPM and ROA had positive but insignificant influence on stock price. DER, ROE, and EPS had negative and insignificant influence on stock price. ROA had negative and significant influence on financial distress level. Firm size, Current Ratio, DER, ROE, EPS, and PER had negative and insignificant influence on financial distress level. Meanwhile, firm age had positive but insignificant influence on financial distress level, and NPM had positive and significant influence on financial distress level. Financial distress level mediated the influence of DER, ROE, and EPS on stock price. Meanwhile, financial distress level did not mediate size, firm age, Current Ratio, NPM, and PER on StockPrice.
\end{abstract}

Keywords: Firm Size, Firm Age, CR, DER, ROA, ROE, NPM, EPS, and PER, Stock Price, Financial Distress Level

\section{Introduction}

The fluctuation of capital prices become an interesting phenomenon to talk about. (Supriyanto, 2013) states that economic growth certainly requires a clear indicator that can be described the economic tide of a country. One of the indicators used is the steady and stable growth of the financial sector. The global economic crisis that occurred in 2008 had a major impact on the Indonesian capital market as reflected by the decline in stock prices up to 40-60 percent from the position early in 2008 (kompas.com), caused by the action to release shares by foreign investors in need of liquidity and worsened by the action "iku-followan" from domestic investors are busy busy release its shares.

Stock price formation is inseparable from accounting information. (Iskandar $\mathrm{z}$. Alwi, 2003) suggests several factors that affect stock prices, among others, internal 
factors and external companies. Internal factor companies that affect the movement of stock prices is reflected from the company's financial statements by looking at the financial ratios of the company itself. Investors assess a company in investing in a company looking at its financial condition. If the company achieves a good performance it will be more attractive to investors. This is consistent with signaling theory.

While financial distress is a factor that is greatly avoided by companies and investors. (Tanuwijaya, 2013) states that the financial factors represented by liquidity ratios, market ratios, managerial ownership and institutional ownership have a significant positive effect on the level of financial distress.

The linkage between the characteristics and financial condition of the company to the level of a company's financial distress will give effect to the stock price. This was stated by (Nurdin, 2012) in his research which gave the result that testing regarding the financial distress of a company contributes to changes in stock prices on the Stock Exchange. In this study, the level of financial distress used as one of the indicators of the movement of stock prices in the capital market. Moreover, liaison between the condition of the company towards stock prices. The purpose of this study is to examine the effect of firm size, firm age, CR, DER, ROA, ROE, NPM, EPS and PER to stock price of stock either partially or simultaneously. To examine the effect of firm size, company age, CR, DER, ROA, ROE, NPM, EPS and PER to the level of financial distress shares either partially or simultaneously. To test the effect of firm size, company age, CR, DER, ROA, ROE, NPM, EPS and PER against stock price through financial distress level.

\section{The Literature And Development Of Hypotheses}

a Stock Price

According to (Anoraga, $\mathrm{P}$ and Pakarti, 2001) the market price of a stock is the price of an ongoing market or if the market is closed, then the stock price is the closing price.

b Company size

According to Grier in (Christiawan, 2014), firm size has different effects on stock prices. In this case the size of the company seen from the log of total assets owned by the company, which can be used for the company's operations. Company Size $=$ Ln Total Assets

c Age of Company

According to (Bestivano, 2013), the age of the company is the age since the company's departure until the company has been able to run its operations.

d Current Ratio (CR)

(Harahap, 2011) argued that the current ratio is the ratio used to measure the ability of companies to pay short-term obligations.

Current Ratio $=\frac{\text { Current Assets }}{\text { Current Liability }}$

e Debt to Equity Ratio (DER)

(Harahap, 2011) stated debt to equity is debt to equity ratio that reflects the ability of the company to fulfill all its obligations indicated by what part of its own capital used to pay the debt. 
Debt to Equity Ratio $=\frac{\text { Total Liability }}{\text { Owners Equity }}$

f Return on Assets (ROA)

(Hermanto, 2012) states that Return on Assets (ROA) is the ratio used in describing the size of the company's effectiveness in utilizing all sources of resources

$\mathrm{ROA}=\frac{\mathrm{EAT}}{\text { Total Assets }}$

g Return on Equity (ROE)

(Brigham, E. F. and Houston, 2009), Return on Equity (ROE) represents the usual rate of return on equity is to measure the return on investment of ordinary shareholders.

$$
\mathrm{ROE}=\frac{\mathrm{EAT}}{\text { Equity }}
$$

h Net Profit Margin (NPM)

(Harahap, 2011) suggests Net Profit Margin (NPM) as a ratio that describes the amount of net profit obtained by the company on every penjulan made.

Net Profit Margin $=\frac{\text { EAT }}{\text { Sales }}$

i Earning Per Share (EPS)

(Fahmi, 2012), Earning per Share (EPS) is contributing the benefit given to the owner of the stock from every stock they own.

EPS $=\frac{\text { Profit share }}{\text { Total Share }}$

j Price Earning Ratio (PER)

(Jogiyanto, 2003), Price Earing Ratio (PER) is the measurement for market to give the value on the company.

PER $=\frac{\text { Market Share Price }}{\text { Net Profit }}$

k Financial Distress Level

Financial distress Based on (Afriyeni, 2012) it is the condition where the financial of the company shows bad or in risc. The level of financial distress experienced by a company using the Alman Z-Score method.

Z-Score $=1.2 \mathrm{~T}_{1}+1.4 \mathrm{~T}_{2}+3.3 \mathrm{~T}_{3}+0.6 \mathrm{~T}_{4}+0.999 \mathrm{~T}_{5}$

The concept of this research can be seen as follow: 


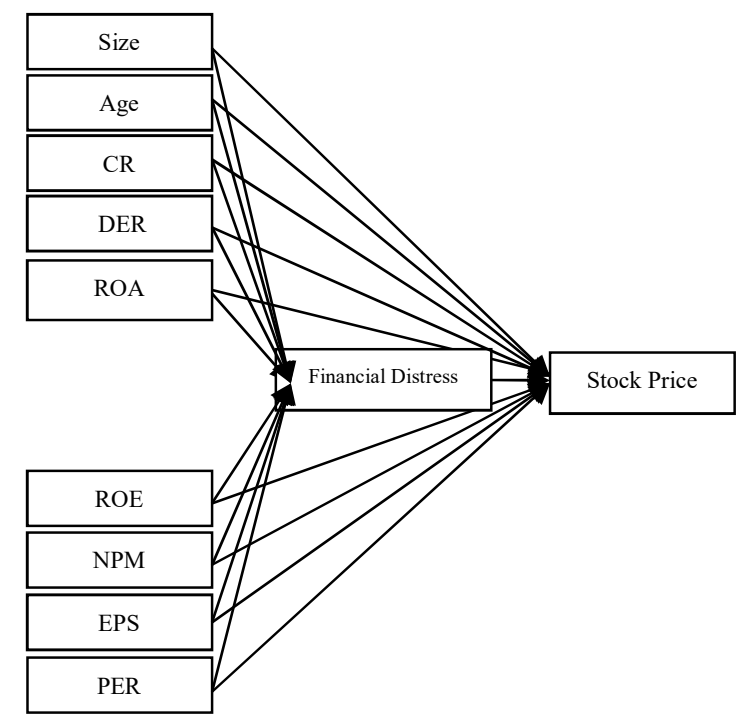

Fig. 1. Conceptual Framework.

The research hypothesis based on literature review and conceptual framework is:

H1: There is influence of company size, company age, CR, DER, ROA, ROE, NPM, EPS and PER against Stock Price

H2: There is influence of company size, company age, CR, DER, ROA, ROE, NPM, EPS and PER to the level of financial distress

H3: There is influence of company size, company age, CR, DER, ROA, ROE, NPM, EPS and PER against Share Price through Financial Distress Level

This type of research is comparative causal. This research was conducted at a manufacturing company listed on Indonesia Stock Exchange 2010-2014. Criteria of sample selection by purposive sampling, with the following criteria; (1) manufacturing company listed on the Indonesia Stock Exchange during observation year (2) publish financial statements supplemented with variables observed during the observation year Based on the criteria; a sample of 73 companies was obtained for 5 years. Methods of data analysis in this study using descriptive statistics, multiple regression, path analysis for intervening variables.

\section{Results}

3.1 Descriptive Statistic

Table 1. Descriptive Statistics.

\begin{tabular}{llllll}
\hline & $\mathrm{N}$ & Minimum & Maximum & Mean & Std. Deviation \\
\hline Size & 365 & 23.27 & 38.26 & 27.9815 & 2.04 \\
\hline Age & 365 & 2 & 37 & 19.15 & 5.98 \\
\hline CR & 365 & 8 & 46488 & 411.65 & 2743.74 \\
\hline DER & 365 & -3060.26 & 12742.95 & 137.4551 & 727.93 \\
\hline ROA & 365 & -42.04 & 280.96 & 7.6671 & 18.34 \\
\hline
\end{tabular}




\begin{tabular}{llllll}
\hline ROE & 365 & -608.81 & 968.55 & 13.7425 & 70.28 \\
\hline NPM & 365 & -204.04 & 409.75 & 6.3145 & 26.75 \\
\hline EPS & 365 & -3134.00 & 55576.00 & 830.1680 & 4400.50 \\
\hline PER & 365 & -1400.00 & 3350.00 & 22.3610 & 211.59 \\
\hline Stock Rate & 365 & 50.00 & 740000.00 & 12086.09 & 56274.62 \\
\hline Finc.Distress & 365 & 1.00 & 3.00 & 1.71 & 0.83 \\
\hline Valid N (listwise) & 365 & & & & \\
\hline
\end{tabular}

Source: Result of The Research, 2015

\subsection{Hypothesis}

\subsubsection{Influence of company size, company age, CR, DER, ROA, ROE, NPM, EPS and PER against Stock rate}

$\mathrm{R}$ Square $=0.334$. This means that $33.4 \%$ of stock price variables can be explained by firm size, company age, CR, DER, ROA, ROE, NPM, EPS and PER. The remaining $66.6 \%$ is explained by other factors outside the research variables.

Based on result ANOVA, it is known that F test value is 14,027 with sig 0,000. This means that firm size variables, company age, CR, DER, ROA, ROE, NPM, EPS and PER have significant influence on stock prices $(0,000<0.05)$.

The regression equation constructed for this hypothesis is:

$$
\begin{array}{r}
\mathrm{Y}=-2,846+2,147 \mathrm{X} 1+0,518 \mathrm{X} 2+0,173 \mathrm{X} 3-0,042 \mathrm{X} 4+0,015 \mathrm{X} 5-0,030 \mathrm{X} 6+ \\
0,053 \times 7-0,027 \times 8+0,056 \mathrm{X} 9
\end{array}
$$

The effect of firm size (X1) to stock price (Y) is 2,147 with sig $0,007<0,05$, it means firm size (X1) has positive and significant influence to stock price (Y).

The influence of company's age (X2) to stock price (Y) is 0,518 with sig 0,000 $<0,05$, meaning that company's age (X2) has positive and significant influence to stock price (Y). Current Ratio (X3) has influence to stock price (Y) equal to 0,173 with sig $0,002<0,05$, meaning Current Ratio (X3) have positive and significant influence to Stock Price (Y). Debt to Equity Ratio (X4) has influence to stock price (Y) equal to 0,042 with sig $0,262>0,05$, it can be concluded that DER (X4) has negative but not significant influence to stock price (Y). Return On Assets (X5) has influence to stock price equal to 0,015 with sig $0,614>0,05$ meaning ROA (X5) have positive but not significant influence to stock price (Y). Return On Equity (X6) has influence to stock price equal to $-0,03$ with sig $0,607>0,05$ meaning $\mathrm{ROE}(\mathrm{X} 6)$ has negative but not significant influence to stock price (Y). Net Profit Margin (X7) has an effect on Stock Price (Y) of 0.053 with sig $0.349>0.05$ means that NPM (X7) has a positive but insignificant effect on stock price (Y). Earning Per Share (X8) has influence to stock price (Y) equal to $-0,027$ with sig $0,243>0,05$ meaning EPS (X8) have negative but not significant influence to stock price (Y). Price Earning Ratio (X9) has influence to stock price (Y) equal to 0,056 with sig $0,009<0,05$ meaning PER (X9) has positive and significant influence to stock price (Y).

\subsubsection{Influence of Company Size, Company Age, CR, DER, ROA, ROE, NPM,} EPS and PER to the level of Financial Distress

The value of $\mathrm{R}$ Square is 0.108 which means that it is $10,8 \%$ variable of financial distress level explained by company size, company age, CR, DER, ROA, ROE, NPM, EPS and PER. The remaining $89.2 \%$ is explained by other factors outside the research model. 
Given $\mathrm{F}$ test value of 3.403 with sig 0.001 . This means that firm size variables, company age, CR, DER, ROA, ROE, NPM, EPS and PER have significant influence on the level of financial distress $(0.001<0.05)$.

The structural equations constructed for this hypothesis are:

$\mathrm{Z}=-0.884 \mathrm{X} 1+0.148 \mathrm{X} 2-0.349 \mathrm{X} 3-0.147 \mathrm{X} 4 \neg-0.466 \mathrm{X} 5 \neg-0.224 \mathrm{X} 6+0.425 \mathrm{X} 7-$ $0.092 \mathrm{X} 8-0.037 \mathrm{X} 9$

The influence of firm size (X1) to the level of financial distress (Z) of -0.884 with sig $0.770>0.05$ means firm size $(\mathrm{X} 1)$ has a negative but not significant influence on the level of financial distress $(Z)$. The influence of firm age (X2) to financial distress (Z) level is 0,148 with sig $0,477>0,05$ meaning company age (X2) has positive but not significant influence to financial distress $(Z)$ level. The influence of current ratio (X3) to financial distress level is -0.349 with sig 0,091>0,05 meaning CR (X3) has negative but not significant influence to financial distress $(Z)$ level. The influence of Debt to Eqity Ratio (X4) to the level of financial distress $(Z)$ of -0.147 with sig $0.306>0.05$ means DER (X4) has a negative but not significant influence on the level of financial distress (Z). The effect of Return On Assets (X5) on the level of financial distress (Z) of -0.466 with sig $0,000<0.005$ means ROA (X5) has a negative and significant influence on the level of financial distress (Z). The influence of Return On Equity (X6) to the level of financial distress $(Z)$ of -0.224 with sig $0.315>0.05$ means ROE (X6) has a negative effect is not significant to the level of financial distress $(Z)$. The influence of Net Profit Margin (X7) to the level of financial distress (Z) of 0.425 with sig 0.049 $<0.05$ means that NPM (X7) has a positive and significant effect on the level of financial distress $(Z)$. The effect of earnings per share (X8) on the level of financial distress (Z) of -0.092 with sig 0.290 means that EPS (X8) has no significant negative effect on the level of financial distress (Z). The effect of Price Earning Ratio (X9) on the level of financial distress $(Z)$ is $-0,037$ with sig $0,646>0,05$ mean PER (X9) has negative effect not significant to financial distress $(Z)$ level.

\subsubsection{Influence of Company Size, Company Age, CR, DER, ROA, ROE, NPM, EPS and PER Against Share Price through Financial Distress Level}

The value of $\mathrm{R}$ Square is 0.352 which means $35.2 \%$ of stock price variables are explained by firm size, company age, CR, DER, ROA, ROE, NPM, EPS and PER through financial distress level. The remaining $64.8 \%$ is explained by other factors outside the research model

F test value of 13,621 with sig 0,000 . This means that firm size variables, company age, CR, DER, ROA, ROE, NPM, EPS and PER have a significant influence on stock prices through the level of financial distress $(0,000<0.05)$.

The structural equations constructed for this hypothesis are:

$\begin{aligned} \mathrm{Y}= & 2,109 \mathrm{X} 1+0,524 \mathrm{X} 2+0,158 \mathrm{X} 3-0.049 \mathrm{X} 4 \neg-0.005 \mathrm{X} 5 \neg--0,040 \mathrm{X} 6+0.071 \mathrm{x} 7- \\ & 0.030 \mathrm{X} 8+0.054 \mathrm{X} 9-0.043 \mathrm{(10)}\end{aligned}$

The effect of total firm size (X1) on stock price (Y) through financial distress (Z) level is 2,147 . The direct effect gained is greater than indirect influence, thus it is known that the level of financial distress does not mediate the effect of firm size (X1) on stock price (Y). 
Influence of total age of company (X2) to stock price (Y) through level of financial distress $(Z)$ equal to 0,518 . The direct influence gained is greater than indirect influence, thus it is known that the level of financial distress does not mediate the influence of firm age (X2) on stock price (Y).

The effect of total current ratio (X3) on stock price $(\mathrm{Y})$ through the level of financial distress $(\mathrm{Z})$ of 0.173 . The direct effect gained is greater than the indirect effect, so it is known that the level of financial distress does not mediate the influence of current ratio (X3) on the stock price (Y).

The effect of total Debt to Equity Ratio (X4) on stock price (Y) through financial distress $(Z)$ level is $-0,043$. The direct effect gained is less than the indirect effect, thus it can be seen that the level of financial distress mediates the influence of Debt to Equity Ratio (X4) on stock price (Y). The total influence of Return On Assets (X5) on stock price $(\mathrm{Y})$ through financial distress $(\mathrm{Z})$ level is 0,015 . The direct effect gained is less than the indirect effect, thus it can be seen that the level of financial distress mediates the significant effect of Return On Assets (X5) on stock price (Y).

The effect of total Return on Equity (X6) on stock price (Y) through financial distress $(Z)$ level is $-0,030$. The direct effect gained is less than the indirect effect, thus it can be seen that the level of financial distress mediates the effect of Return on Equity (X6) on the stock price (Y). The net effect of Net Profit Margin (X7) on stock price (Y) through financial distress $(Z)$ level is 0,053 . The direct influence gained is greater than the indirect effect, thereby knowing the level of financial distress does not mediate the effect of Net Profit Margin (X7) on stock price (Y) through financial distress (Z) level. The effect of total Earning Per Share (X8) on stock price (Y) through the level of financial distress $(Z)$ of -0.026 . Direct influence gained is less than indirect influence, it can be concluded that the level of financial distress mediate the influence of Earning Per Share (X8) to the stock price (Y). The total influence of Price Earning Ratio (X9) on stock price $(\mathrm{Y})$ through financial distress $(\mathrm{Z})$ level is 0,056 . Direct influence gained greater than indirect influence, it can be concluded that the level of financial distress does not mediate the influence of Price Earning Ratio (X9) on stock prices (Y). Simultaneously influence of size, age, current ratio, debt to equity ratio ROA, ROE, NPM, EPS, and PER to stock price with mediated level of financial distress seen from total direct influence and total indirect influence. Total direct influence 2,792> total indirect influence 0,070 . It can be concluded that simultaneously the level of financial distress does not mediate the effect of size, age, current ratio, debt to equity ratio ROA, ROE, NPM, EPS, and PER against stock prices.

\section{Conclusions}

Conclusions From the results of research conducted can be concluded as follows: 1 . Partially Size, age of company, Current Ratio, and PER have positive and significant influence to stock price. While NPM and ROA have a positive but not significant influence on stock prices. While DER, ROE, and EPS have a negative effect is not significant to stock prices. Simultaneously size, age of company, current ratio, debt to equity ratio, ROA, ROE, NPM, EPS and PER have significant effect to stock price 2. ROA has a negative and significant influence on the level of financial distress. The size of the firm, Current Ratio,DER, ROE, EPS and PER have no significant negative effect on the level of financial distress. NPM has a positive and significant influence on the level of financial distress. While the age of the company has a positive but not 
significant influence on the level of financial distress. Simultaneously size, age of company, current ratio, debt to equity ratio, ROA, ROE, NPM, EPS and PER have significant effect to financial distress level.Tingkat financial distress mediate the effect of DER, ROE and EPS on stock prices. The level of financial distress has a significant mediation influence between the influence of ROA on stock prices. While the level of financial distress does not mediate the size, age of the company, current ratio, NPM and PER against stock prices. Suggestions From the conclusions and limitations of the research, the suggestions that can be given are as follows: 1. Investors should be more in-depth in the process of making stock investment decisions within a company. Many considerations should be paid attention, not only look at the financial ratios exposed in the financial statements, but look at the whole of a company that will be the target of investment. 2. Based on the limitations of research, suggestions for further research for similar fields are: a. Adding, reducing or replacing the use of independent variables used in the study, there are other variables. b. Only use one ratio as a representative of each ratio in order to reduce the occurrence of multicollinearity. c. Changing the financial disstress level calculation model with Springgate or Zmijewski model d. Changing the object of research in other corporate sectors, such as banking or BUMN.

\section{References}

[1] Afriyeni, E. (2012) “Model Prediksi Financial Distress", Padang Polibisnis, 110.', 4(2), pp. 1-10.

[2] Anoraga, P and Pakarti, P. (2001) Pengantar Pasar Modal. Revisi. Jakarta: PT. Asdi Mahasatya.

[3] Bestivano, W. (2013) 'Pengaruh Ukuran Perusahaan, Profitabilitas, dan Leverage Terhadap Perataan Laba', 1.

[4] Brigham, E. F. and Houston, J. F. (2009) 'Manajemen Keuangan.'

[5] Christiawan, Y. . (2014) 'Earning Management of Firms Reporrting Lonng Term Debt: An Alternative Method'.

[6] Fahmi, I. (2012) 'Analisis Kinerja Keuangan'.

[7] Harahap, S. . (2011) Teori Akuntansi Edisi Revisi.

[8] Hermanto (2012) 'Bentuk Kerjasama Nazhir dengan Lembaga Keuangan Syariah dalam Pengelolaan Wakaf Tunai'.

[9] Iskandar z. Alwi (2003) Pasar Modal: Teori dan Aplikasi. Yayasan Pancur Siwah.

[10] Jogiyanto (2003) 'Teori Portofolio dan Analisis Sekuiritas Yogyakarta BPFE'.

[11] Nurdin, I. (2012) "Peranan Analisis Metode Z-Score dalam Memprediksi Kebangkrutan Suatu Perusahaan dan Kaitannya Terhadap Harga Saham (Studi Pada Perusahaan Perbankan Yang Go Public Di Bursa Efek Indonesia ).', Jurnal Skripsi Fakultas Ekonomi Jurusan Akuntansi.

[12] Supriyanto, S. (2013) 'Pengaruh Kinerja Keuangan Terhadap Pendapatan Saham Perbankan Di Bursa Efek Indonesia. Administrasi', Jurnal Bis-A: Jurnal Bisnis, 2(1), pp. 39-53.

[13] Tanuwijaya, L. (2013) 'Analisis Faktor-Faktor Internal dan Eksternal Perusahaan yang Mempengaruhi Kesulitan Keuangan (Financial Distress) Pada Perusahaan Sektor Manufaktur Yang Terdaftar di BEI', Universitas Katolik Soegijapranata.' 